\title{
Analysis of factors affecting the quality of life of those suffering from Crohn's disease
}

\author{
Authors' Contribution: \\ A-Study Design \\ B-Data Collection \\ C-Statistical Analysis \\ E-Manuscript Preparation \\ F-Literature Search \\ G-Funds Collection \\ Joanna Chrobak-Bieńn ${ }^{1 A B C D E F C}$, Anna Gawor ${ }^{2 A D F}$, Małgorzata Paplaczyk ${ }^{3 A D F}$, Ewa Małecka-Panas ${ }^{4 A D F}$, \\ Anita Cąsiorowska ${ }^{5 A D E F}$ \\ 'Department of Gastrointestinal Diseases, University Clinical Hospital No. 1 in Łódź, Doctoral Study Program, Faculty of Medicine, Medical \\ University of Łódź \\ ${ }^{2}$ Department of Internal Medicine and Environmental Nursing, Faculty of Health Sciences, Jagiellonian University Medical College, Kraków \\ ${ }^{3}$ Doctoral Study Program, Faculty of Health Sciences, Jagiellonian University Medical College, Kraków, University Hospital in Kraków \\ ${ }^{4}$ Department of Gastroenterology, Medical University of Łódź \\ Military Medical Academy Memorial University Clinical Hospital \& Central Veterans' Hospital in Łódź
}

Article history: Received: 16.03.2017 Accepted:26.06.2017 Published: 31.08.2017

ABSTRACT: $\quad$ Introduction. Crohn's disease is an inflammatory bowel disease of unknown etiology. Its chronic nature, as well as symptoms of intestinal and overall significantly impedes the daily functioning of patients. Alternately occurring periods of exacerbation and remission are the cause of reduced quality of life of patients. Understanding the factors that caused the decrease in the quality of life, it allows us to understand the behavior and the situation of the patient and the ability to cope with stress caused by the disease.

Aim of the study. The aim of the study was to analyze the factors affecting the quality of life of people with Crohn's disease.

Material and methods. The study group consisted of 50 people diagnosed with Crohn's disease. Respondents were treated at the Department of Ceneral Surgery and Colorectal Medical University of Lodz and Gastroenterological Clinic at the University Clinical Hospital No. 1 in Lodz. Quality of Life Survey was carried out by a diagnostic survey using a research tool SF-36v2 and surveys of its own design.

Results. Analysis of the results demonstrated that the quality of life of patients with Crohn's disease was reduced, especially during exacerbations. Evaluation of the quality of life of respondents in physical terms was slightly higher than in the mental aspect. Higher education subjects and the lack of need for surgical treatment significantly improves the quality of life.

Conclusions. The occurrence of chronic disease reduces the quality of life of respondents. Elderly patients are better able to adapt to the difficult situation caused by the disease. The quality of life of women and men is at a similar level and patients in remission of the disease have a better quality of life of patients during exacerbations.

KEYWORDS:

quality of life, Crohn's disease, disease activity

\section{INTRODUCTION}

Crohn's disease (CD) belongs to the group of inflammatory bowel diseases of hitherto unknown etiology. The disorder is characterized by segmental inflammatory lesions affecting the entire intestinal wall. The lesions may occur in any segment of the gastrointestinal tract. Most commonly, however, they are located within the terminal ileum (40-50\%) while the lowest incidence of the disease is observed within the upper gastrointestinal tract.

Despite the fact that the etiopathogenesis of CD has not been fully elucidated, genetic, environmental, as well as immune factors are considered to be the main causes of the disorder. Crohn's disease is observed at all geographical latitudes in individuals of all racial origins. The highest increase in morbidity rates is observed in the developed countries including the US, Canada, and Western Europe [1]. The lowest morbidity rates are observed in Africa and Asia. Currently, the morbidity rate in the European Union amounts to about 5 cases per 100,000 patients each year [2]. Despite the fact that CD is a disease that affects mainly young patients (within their second and third decade of life), first symptoms may appear at any age.

Due to its chronic character, $\mathrm{CD}$ is a remittent-relapsing disease that impairs everyday functioning and inescapably reduces the quality of life of the patients [3]. Once diagnosed, the disease persists throughout the patient's life. Besides the treatment of the primary disease, contemporary medicine has another objective of impro- ving the patients' quality of life. The World Health Organization (WHO) defines the quality of life as "an individual's perception of their position in life in the context of the culture and value systems in which they live and in relation to their goals, expectations, standards and concerns" [4]. Negative perception of the disease being incurable favors the onset of depression and further to deterioration of the patient's clinical status. Chronic diseases are also associated with reduced motivation to keeping fit and adapting to the realities of the disease. Acceptation of the disease is tantamount to accepting the limitations and potential impairment caused by this disease. A common consequence of the hitherto incurable CD consists in depressed mood which is caused not only by the basic clinical symptoms of the disease but also to the associated emotional and psychological problems. Despite the efforts of experts, the treatment of these problems is not always successful [5-8]. Therapeutic problems may be due to the lack of appropriate knowledge on the disease as well as the lack of knowledge of the quality of life assessment tools. The consequences amount to acceptation of limitations caused by the disease, lower self-reliance feeling of dependence on others and reduced self-esteem [9]. Obtaining appropriate information on the quality of life deficits as experienced by the patients facilitates better understanding of their behavior and strategies for coping with everyday life and the stress caused by the disease.

The quality of life is associated with the acceptance of the disease and adaptation to the new situation in the patient's life which has 
a significant impact on further well-being of the patient [10]. The assessment of the quality of life of patients coping with chronic diseases including the $\mathrm{CD}$ facilitates identification of factors having the largest impact thereon. Information on health-related quality of life facilitates taking up measures to improve the quality of patient care. The objective of the study was to analyze the factors affecting the quality of life in Crohn's disease patients.

\section{MATERIAL AND METHODS}

The study population consisted of 50 residents of Łódzkie voivodeship previously diagnosed with Crohn's disease. One half of the study group (25 patients) consisted of patients hospitalized at the Department of General and Colorectal Surgery of the Medical University of Łódź. The remaining 25 subjects consisted of subjects treated at the specialist Gastroenterology Clinic at the University Clinical Hospital No. 1 in Łódź. Participation in the study was voluntary and anonymous, and the subjects were informed accordingly. The study started in July 2016 following an approval being obtained from the Bioethics Committee of the Medical University of Łódź (decision no. RNN/177/16/KE dated 14 June 2016). The study was completed on 31 January 2017. The study was conducted in line with the guidelines of Declaration of Helsinki.

The study design consisted of patients being administered the Short Form (36) Health Survey version 2 (SF-36v2) along with a proprietary study questionnaire. Quality of life was assessed using the Polish language version of the licensed SF-36v2 form (Student License Agreement QM035225 - CT177402- OP052598).

The questionnaire allows to comprehensively capture the subjective feelings of patients while the license, standardization and professional translation ensure the reliability of results. The SF36v2 questionnaire consists of 11 questions and facilitates the assessment of the quality of life in individual domains including physical functioning ( PF), role limitations due to physical problems (RP), bodily pain (BP), general health perception (GH), vitality (VT), social functioning (SF), mental health $(\mathrm{MH})$, role limitations due to emotional problems (RE), and health transition (HT). The above categories are grouped into two main summaries: the physical component summary (PCS) including PF, RP, BP, and GH and the mental component summary (MCS) including VT, SF, RE, and $\mathrm{MH}[11,12]$. The quality of life is assessed in each domain using a 0 to 100 scale. The higher the score, the higher the quality of life. No reference standards are available for SF-36v2 and therefore one may not conclude whether the results of responders correspond to a high or a low quality of life. One may only compare individual domains to identify the areas of the best and the poorest quality.

Our proprietary questionnaire consisted of 22 questions regarding the duration of the disease, symptoms, complications, treatment and demographic variables.

The statistical analysis of quantitative (i.e. numerical) variables consisted of calculation of means, standard deviations, medians, quartiles as well as the minimum and maximum values.

Qualitative (i.e. non-numerical) variables were summarized by the numbers and percentages of occurrence of each particular value. Quantitative variables were compared between the two groups



Fig. 1. Quality of life of the patients depending on the stage of the disease.

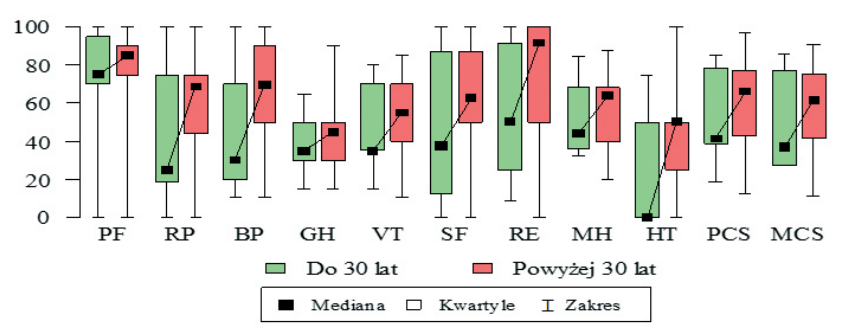

Fig. 2. The quality of life of patients, depending on age.

using the Student's t-test (when variables followed the normal distribution curve within the groups) or using the Mann-Whitney's U-test (when normal distribution could not be observed). The comparison of quantitative variables between three and more groups was made using the analysis of variance (ANOVA) (when variables followed the normal distribution curve within the groups) or using the Kruskal-Wallis test (when normal distribution could not be observed). Post-hoc analyses using Tukey's HSD test (for normal distributions) or Dunn's test (for non-normal distributions were carried out for statistically significant differences being observed in the comparisons. Normal distribution of variables was verified using the Shapiro-Wilk's test. The significance level was defined as 0.05 ; all values with $\mathrm{p}<0.05$ were considered to be significantly correlated. The analyses were carried out using the $\mathrm{R}$ software version 3.3.2.

\section{RESULTS}

Responses were obtained from all patients over the entire scheduled study period. The results were subjected to statistical analyses and subsequently processed and presented as tables and figures.

The study population consisted of 25 male and 25 female patients. The mean age of the entire group was $35.72(\mathrm{SD}=10.78)$ years. The mean age of the female subpopulation was 29.92 as compared to 27.72 in the male subpopulation. The youngest responder was 20 years old while the oldest one was 69 years old. Most responders (90\%) declared to be residents of urban areas. More than one half of the responders had higher educational background (56\%) as compared to $36 \%$ of responders with medium educational background and $8 \%$ of responders with vocational educational background. The vast majority of the subjects (86\%) were professionally active, with $6 \%$ studying, $6 \%$ receiving disability pension due to the disease and 1 person (2\%) being retired. The mean duration of the disease was $5.92(\mathrm{SD}=4.59)$ years. The vast majority of subjects (94\%) were aware of the negative health consequences of smok- 


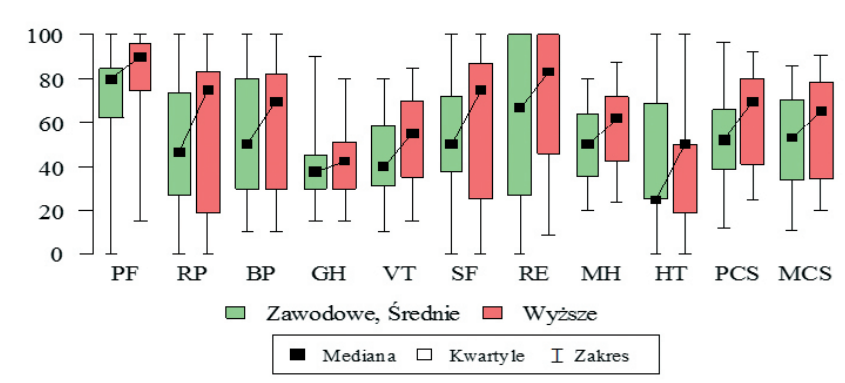

Fig. 3. The quality of life of patients, depending on education.

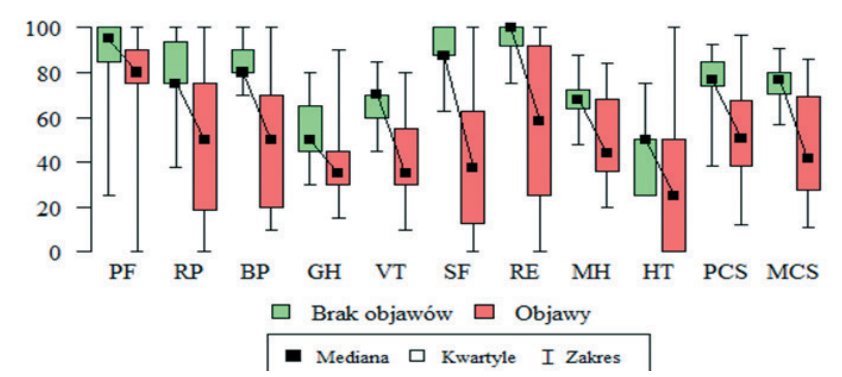

Fig. 4. Quality of life of patients, depending on the symptoms.

ing and did not smoke cigarettes or other tobacco products. Table 1 presents the clinical characteristics of the study population.

The next part of the study consisted in the statistical analysis of the quality of life of $C D$ patients in individual domains. The best scores were provided in PF, RE, and PCS domains while the lowest scores were most prevalent in VT, GH, and HT domains. The responders scored slightly lower with regard to the mental component summary (MCS) as compared to the physical component summary (PCS). Table 2 illustrates the quality of life scores for individual domains.

Out of the entire study population, 19 patients were in remission while the remaining 31 patients were in the active phase of the disease. The statistical analysis of the data on the quality of life of patients depending on the disease phase (remission vs. exacerbation) revealed $\mathrm{p}<0.001$ for the PF, RP, BP, GH, VT, SF, RE, MH, PCS, and MCS domains; this means that the quality of life of patients depended on the phase of the disease. The quality of life was higher in remittent patients than in those experiencing an exacerbation (Chart 1). The HT domain was the only one in which no correlation between the disease phase and the quality of life was observed $(p=0,12)$.

The statistical analysis of data revealed no statistically significant differences between the patients' gender and the quality of life. Further analysis of data focused on verification of a potential statistically significant correlation between the age and the quality of life of patients. The comparisons of scores in the BP, SF, RE, and HT domains had p values of less than 0.05 , i.e. The quality of life in those domains was age-dependent. The quality of life increased with age as evident in the group of patients above the age of 30 . The results are presented in Chart 2.

Further statistical analysis focused on the relationship between the educational background and employment on the quality of life of responders. Only 4 patients in the study group had vocational
Tab. I. Clinical characteristics of the study group.

\begin{tabular}{|c|c|c|c|}
\hline FEATURE & & $\mathbf{N}$ & $\%$ \\
\hline \multirow{4}{*}{ Disease form } & Remission & 19 & 38 \\
\hline & Mild & 12 & 24 \\
\hline & Moderate & 13 & 26 \\
\hline & Severe & 6 & 12 \\
\hline \multirow{3}{*}{$\begin{array}{l}\text { Impact of the disease } \\
\text { on the chosen job }\end{array}$} & Yes & 23 & 46 \\
\hline & No & 26 & 52 \\
\hline & Not applicable *** & 1 & 2 \\
\hline \multirow{3}{*}{$\begin{array}{l}\text { Job change required } \\
\text { due to the disease }\end{array}$} & Yes & 13 & 26 \\
\hline & No & 36 & 72 \\
\hline & Not applicable ${ }^{* * *}$ & 1 & 2 \\
\hline \multirow{4}{*}{$\begin{array}{l}\text { The impact of the } \\
\text { disease on the } \\
\text { relationships with } \\
\text { others }\end{array}$} & Very strong & 1 & 2 \\
\hline & Strong & 11 & 22 \\
\hline & Some & 21 & 42 \\
\hline & None & 17 & 34 \\
\hline \multirow{4}{*}{$\begin{array}{l}\text { Negative impact on } \\
\text { family relationships }\end{array}$} & Very strong & 0 & 0 \\
\hline & Strong & 2 & 4 \\
\hline & Some & 28 & 56 \\
\hline & None & 20 & 40 \\
\hline \multirow{4}{*}{$\begin{array}{l}\text { Satisfaction of } \\
\text { patient's private life }\end{array}$} & Very satisfied & 6 & 12 \\
\hline & Satisfied & 16 & 32 \\
\hline & Neither satisfied nor dissatisfied & 20 & 40 \\
\hline & Dissatisfied & 8 & 16 \\
\hline \multirow{5}{*}{$\begin{array}{l}\text { Sources of } \\
\text { knowledge } \\
\text { on the disease* }\end{array}$} & TV, Internet & 37 & 74 \\
\hline & Physician, nurse & 45 & 90 \\
\hline & Patient associations & 14 & 28 \\
\hline & Books, press & 22 & 44 \\
\hline & Other (studies, other patients) & 3 & 6 \\
\hline \multirow{10}{*}{ Clinical symptoms } & Perianal fistulae & 7 & 14 \\
\hline & Internal fistulae & 3 & 6 \\
\hline & Anal fissures & 3 & 6 \\
\hline & Abscesses & 8 & 16 \\
\hline & Intestinal stenosis & 17 & 34 \\
\hline & Anemia & 13 & 26 \\
\hline & Skin lesions & 15 & 30 \\
\hline & Arthritis & 14 & 28 \\
\hline & Iritis & 0 & 0 \\
\hline & None of the above & 13 & 26 \\
\hline \multirow{4}{*}{$\begin{array}{l}\text { Surgical procedures } \\
\text { due to the disease }\end{array}$} & None & 22 & 44 \\
\hline & Once & 18 & 36 \\
\hline & Twice & 7 & 14 \\
\hline & 3 times & 3 & 6 \\
\hline \multirow{6}{*}{$\begin{array}{l}\text { Types of earlier } \\
\text { surgical procedures* }\end{array}$} & Small intestinal resection & 8 & 16 \\
\hline & Large intestinal resection & 12 & 24 \\
\hline & Abscess & 8 & 16 \\
\hline & Inflammatory abdominal tumor & 0 & 0 \\
\hline & Fistulae & 7 & 14 \\
\hline & $\begin{array}{l}\text { Other (sigmoidocecal resection, } \\
\text { intestinal stenosis plasty) }\end{array}$ & 2 & 4 \\
\hline
\end{tabular}
*The percentages do not add up to 100 due to the multiple answers being allowed.
$* *$ The patient never worked 
educational background and were this group was combined with that consisting of patients with medium educational background. A $p<0.05$ value was observed in the PF domain which means that physical functioning depended on the educational background of patients. Patients with higher education were shown to present with better quality of life scores than patients with vocational or medium education (Chart 3). Three individuals within the study population were students, another 3 received disability pensions while another 1 subject was retired. All these subjects were combined in a group of "non-working" subjects. All the p scores exceeded 0.05 for all domains of the SF36v2 survey demonstrating that the quality of life of the patients did not depend on their occupational activity (Table 3 ).

Further study focused on the analysis of the quality of life depending on the experienced clinical symptoms (including non-gastrointestinal symptoms). Comparisons of PF, RP, BP, GH, VT, SF, RE, MH, PCS, and MCS showed $\mathrm{p}<0.05$ for all types of symptoms experienced by the subjects. Patients experiencing no additional, non-gastrointestinal symptoms reported higher quality of life scores. Only within the HT domain the clinical symptoms had no impact on the quality of life of the responders $(p=0.171)$. The results of the study are presented in Chart 4.

Patients were divided into three groups according to their responses to one of the questions in the proprietary questionnaire pertaining to the history of surgical treatment for CD. The first group consisted of surgical treatment-naive patients. The second group consisted of subjects with the history of one surgical procedure whereas the third group consisted of subjects who had undergone two or more surgical procedures due to their primary disease. The statistical analysis revealed $\mathrm{p}<0.05$ for the PF, RP, BP, GH, VT, SF, $\mathrm{RE}, \mathrm{MH}, \mathrm{PCS}$, and MCS domains; this means that the quality of life of patients depended on the history of surgical treatment. Post-hoc analysis was performed to examine the observed correlation in more detail. It showed that in every of the aforementioned domains, patients naive to surgical treatment reported higher quality of life scores compared to patients who had undergone surgeries. The results of the analysis are presented in Chart 5.

\section{DISCUSSION}

As a chronic disease, CD has a significant and multifactorial impact on every domain of human life. It forces patients to change their lifestyles while simultaneously causing trouble in performing their daily duties and social roles. The problem is all the more important that the disease largely affects young individuals who just start their professional careers and establish their families. The chronic character of $C D$ together with clinical symptoms occurring in a recurrent, severe and oftentimes unpredictable fashion gastrointestinal tract as well as in other organs significantly reduces the quality of life of individuals affected by the disease. Ability to maintain self-reliance in everyday activities, improvement in one's well-being, and pursuit to improve one's abilities and the quality of life should constitute a measure the efficacy and control provided by therapeutic and rehabilitation approach $[13,14]$.

As demonstrated in our studies, patients with remittent disease reported better quality of life than patients experiencing exacerbations of the disease. This result was consistent with observations
Tab. II. Quality of life domains

\begin{tabular}{|llllllll|}
\hline DOMAIN & MEAN & SD & MEDIAN & MIN & MAX & Q1 & Q3 \\
\hline PF & 77,4 & 24,91 & 82,5 & 0 & 100 & 75 & 95 \\
\hline RP & 54,25 & 30,94 & 56,25 & 0 & 100 & 20,31 & 75 \\
\hline BP & 56,8 & 29,45 & 55 & 10 & 100 & 30 & 80 \\
\hline GH & 41,2 & 17,72 & 40 & 15 & 90 & 30 & 50 \\
\hline VT & 48,5 & 22,11 & 50 & 10 & 85 & 35 & 70 \\
\hline SF & 54,75 & 33,3 & 50 & 0 & 100 & 28,12 & 87,5 \\
\hline RE & 67,33 & 33,11 & 75 & 0 & 100 & 33,33 & 100 \\
\hline MH & 54,4 & 19,12 & 56 & 20 & 88 & 36 & 68 \\
\hline HT & 39 & 29,95 & 37,5 & 0 & 100 & 25 & 50 \\
\hline PCS & 58,58 & 21,1 & 63,08 & 12,31 & 96,92 & 38,85 & 78,08 \\
\hline MCS & 55,02 & 23,21 & 56,92 & 10,77 & 90,77 & 34,23 & 76,54 \\
\hline
\end{tabular}

Q1, Q3-quartiles

made in other studies by other authors. In a study conducted in several hospitals in Spain, Casellas et al. observed a deterioration in the quality of life of patients with active (i.e. Exacerbated) disease as compared to patients in remission [15]. A Polish study by Andrzejewska et al. [16] examined the quality of life of patients with Crohn's disease. In a group of 92 responders with inflammatory bowel disease, 41 patients were diagnosed with CS. The results were indicative of the quality of life being worse in disease exacerbation as compared to remission [16]. As a chronic disease, CD often leads not only to physical, but also to psychosocial disabilities. As shown by the results of our study, the responders scored slightly lower with regard to the mental component summary (MCS) as compared to the physical component summary (PCS). In 2008, a Swedish research group conducted a study to demonstrate that most frequent complains reported by CD patients pertained to limitations due to lack of vitality and intensity of disease symptoms, particularly pain [17]. In another study carried out to assess the quality of life of patients with inflammatory bowel diseases Henrich and Herschbach demonstrated that this population of patients is characterized by lack of satisfaction in individual domains of life (relaxation, rest, energy level, physical condition) that increased with the increased activity of the disease [18].

Despite the fact that CD may occur in patients of any age, two peak incidence age ranges are observed, the first between the age of 15 and 35 and the second after the age of $60[19,20]$. In our own study, a larger part of responders was relatively young (mean age 35.72 for the entire population) and had a higher educational background (56\%). The analysis of the impact of age on the quality of life of patients showed that the quality of life increased with patients' age. This correlation may be due to the financial as well as professional status of patients becoming more stable as they grow older. Individuals after the age of 30 commonly had their life partners and children who were able to provide provided unmeasurable support in their disease. Similarly, Bączyk et al, demonstrated that individuals above the age of 30 and with higher educational background reported higher quality of life scores with regard to intestinal symptoms as well as the systemic and emotional functioning [21]. However, the cited study revealed no statistically significant correlation between the area of residence or the gender and the quality of patient's life. The results of our own study confirm these observations. 
Tab. III. Quality of life of patients, depending on the activity

\begin{tabular}{|c|c|c|c|c|c|c|c|c|c|c|}
\hline DOMAIN & PROFESSIONAL ACTIVITY & N & MEAN & SD & MEDIAN & MIN & MAX & Q1 & Q3 & $P^{*}$ \\
\hline \multirow{2}{*}{ PF } & Working patients & 43 & 77,56 & 26,15 & 85 & 0 & 100 & 75 & 95 & 0,398 \\
\hline & Non-working patients & 7 & 76,43 & 16,76 & 80 & 45 & 95 & 70 & 87,5 & \\
\hline \multirow{2}{*}{ RP } & Working patients & 43 & 55,81 & 32,17 & 68,75 & 0 & 100 & 21,88 & 81,25 & 0,325 \\
\hline & Non-working patients & 7 & 44,64 & 21,17 & 50 & 18,75 & 75 & 28,12 & 56,25 & \\
\hline \multirow{2}{*}{ BP } & Working patients & 43 & 58,84 & 29,94 & 70 & 10 & 100 & 30 & 80 & 0,231 \\
\hline & Non-working patients & 7 & 44,29 & 24,4 & 50 & 20 & 90 & 25 & 50 & \\
\hline \multirow{2}{*}{$\mathrm{GH}$} & Working patients & 43 & 42,21 & 16,84 & 40 & 15 & 90 & 30 & 50 & 0,215 \\
\hline & Non-working patients & 7 & 35 & 22,91 & 35 & 15 & 80 & 17,5 & 40 & \\
\hline \multirow{2}{*}{ VT } & Working patients & 43 & 50,47 & 22,41 & 55 & 10 & 85 & 35 & 70 & 0,101 \\
\hline & Non-working patients & 7 & 36,43 & 16,76 & 35 & 15 & 70 & 30 & 37,5 & \\
\hline \multirow{2}{*}{ SF } & Working patients & 43 & 57,56 & 33,65 & 62,5 & 0 & 100 & 37,5 & 87,5 & 0,128 \\
\hline & Non-working patients & 7 & 37,5 & 27 & 37,5 & 0 & 87,5 & 25 & 43,75 & \\
\hline \multirow{2}{*}{ RE } & Working patients & 43 & 70,93 & 32,5 & 83,33 & 0 & 100 & 41,67 & 100 & 0,067 \\
\hline & Non-working patients & 7 & 45,24 & 29,99 & 50 & 8,33 & 100 & 25 & 54,17 & \\
\hline \multirow{2}{*}{$\mathrm{MH}$} & Working patients & 43 & 55,91 & 19,33 & 60 & 20 & 88 & 38 & 70 & 0,207 \\
\hline & Non-working patients & 7 & 45,14 & 15,95 & 40 & 36 & 80 & 36 & 44 & \\
\hline \multirow{2}{*}{ HT } & Working patients & 43 & 40,12 & 29,95 & 50 & 0 & 100 & 25 & 50 & 0,498 \\
\hline & Non-working patients & 7 & 32,14 & 31,34 & 25 & 0 & 75 & 12,5 & 50 & \\
\hline \multirow{2}{*}{ PCS } & Working patients & 43 & 59,64 & 21,83 & 64,62 & 12,31 & 96,92 & 38,46 & 78,46 & 0,585 \\
\hline & Non-working patients & 7 & 52,09 & 15,52 & 50,77 & 40 & 84,62 & 41,54 & 53,08 & \\
\hline \multirow{2}{*}{ MCS } & Working patients & 43 & 57,21 & 23,35 & 61,54 & 10,77 & 90,77 & 36,92 & 76,92 & 0,158 \\
\hline & Non-working patients & 7 & 41,54 & 18,38 & 36,92 & 27,69 & 81,54 & 31,54 & 40,77 & \\
\hline
\end{tabular}

*Mann-Whitney's test

Crohn's disease has a significant impact on all domains of patients' lives. It puts limitations to their emotional, social and professional functioning which in consequence leads to low self-esteem and lack of life satisfaction. In Poland, the available statistical data on the occupational activity of patients with inflammatory bowel diseases are not abundant. However, we know that $35 \%$ of male patients with ulcerative colitis and $42 \%$ patients affected by the same disease end their professional career before the statutory retirement age [22]. A Canadian study showed that a significant percentage (16.5\%) of female CD patients who had been professionally active at the moment of diagnosis were unemployed or received a pension due to being incapable of working. The results of our studies do not match those by other authors. The analysis of our results dhows that the professional activity of responders had no impact on their quality of life.

We were also able to demonstrate that the occurrence of intestinal problems and troublesome non-gastrointestinal symptoms is an important factor responsible for significant deterioration of the quality of life.

Similar results were published by Cassellas et al,, who observed a significant impact of pain and discomfort on the quality of life of the responders [15]. A significant percentage of patients (65.9\%) experiencing disease exacerbation reported pain and discomfort. Bernklev et al. also demonstrated that the incidence of gastrointestinal problems had a significant impact on the quality of life of the patients. The more often the patients reported gastrointestinal problems, the lower were their quality of life scores.

As demonstrated in pour study, the type of treatment also has a significant impact on the quality of life of CD patients. The quali- ty of life scores reported by the group of responders undergoing conservative treatment were better than those reported by patients undergoing surgical treatment. Bączyk et al. also demonstrated low overall quality of life scores reported by patients with inflammatory bowel diseases undergoing treatment in surgical departments [21].

As shown by our study, the quality of life is affected by a number of factors including the phase of the disease, age, presence of clinical symptoms and the treatment regimen. Further studies are required to assess the impact of other aspects such as disease duration, pharmacological treatment regimens and adverse effects associated with these regimens.

\section{CONCLUSIONS}

1. The main factor reducing the quality of life of patients with Crohn's disease consists of chronic gastrointestinal and non-gastrointestinal complaints. A negative impact of the above was observed mainly in relation to the mental component summary.

2. Patients in remission reported significantly better quality of life scores compared to patients with active disease.

3. The lowest quality of life scores were observed in patients below the age of 30 and with medium or vocational educational background.

4. No correlation between gender and the reported health-related quality of life could be observed. 


\section{REFERENCES}

1. Kłopocka M.: Znaczenie bakterii w patogenezie i przebiegu klinicznym nieswoistych chorób zapalnych jelit. Forum zakażeń. 2012; 3: 49-53.

2. Bartnik W.: Wytyczne postępowania w nieswoistych chorobach zapalnych jelit. Przegl. Gastroenterol. 2007, 2 (5), 215-229.

3. Neubauer K., Arlukiewicz A., Paradowski L.: Quality of life in inflammatory bowel disease. Adv. Clin. Exp. Med. 2009; 18 (1): 79-83.

4. WHO. World Health Organisation Definition of Quality of Life. Http://www. int/evidence /assessment-instruments/qol/ql1.htm. (data odwiedzenia strony: 16.11.2016 rok).

5. Skrzypińska K., Kurowska K.: Jakość życia, poczucie koherencji i depresyjność w chorobach przewlekłych. Fundacja „Valetudinaria” - Postępy medycyny klinicznej i wojskowej 2009; 14 (1): 19-23.

6. Kurowska K., Jach B.: Akceptacja choroby i sposoby radzenia sobie ze stresem u chorych na cukrzycę typu 2. Diabetol. Prakt. 2011; 12 (3): 113-119.

7. Wnuk M., Marcinkowski J.T.: Jakość życia w chorobach przewlekłych. Hygeia Public Health. 2013; 48 (3): 274-278.

8. Niedzielski A., Humeniuk E., Błaziak P., Fedoruk D.: Stopień akceptacji choroby w wybranych chorobach przewlekłych. Wiad. Lek. 2007; LX (5-6): 224-227.

9. Juczyński Z.: Narzędzia pomiaru w promocji i psychologii zdrowia. Polskie Towarzystwo Psychologiczne, Warszawa 2001.

10. Walewska E., Ścisło L., Kózka M., Grabowiec P.: Jakość życia chorych z wrzodziejącym zapaleniem jelita grubego. Annales Uniwersitas Mariae Curie-Skłodowska Lublin - Polonia sectio D 2005; LX (supl. XVI): 147-151.

11. Maruish M.E.: Concepts, Measures and Aplications. In: Maruish ME (Ed.) User's Manual for the SF-36v2 Health Survey (3re ed.). Lincoln, RI: Quality Metric Incorporated. 2011: 15-27.

12. Turska W., Skowron A.: Metodyka oceny jakości życia. Farmacja Pol. 2009; 65: 572-580.

13. Bączyk G., Karoń J., Krokowicz P.: Obiektywny i subiektywny wymiar jakości życia osób z nieswoistym zapaleniem jelit leczonych na oddziale chirurgicznym. Przegl. Gastroenterol. 2011; 6 (3): 170-175.

14. Janke K.H., Klump B., Gregor M., Meisner B., Haeusner W.: Determinants of life satisfaction in inflammatory bowel disease. Inflamm. Bowel Dis. 2005; 11 (3): 272-286.

15. Casellas F., Arenas JI., Baudet JS., et al.: Impairment of health- related quality of life in patients with inflammatory bowel disease: A Spanish multicenter study. Inflamm Bowel Dis 2005; 11(5): 488-496.

16. Andrzejewska J., Talarska D.: Jakość życia w nieswoistych zapaleniach jelit. Analiza i walidacja nowego narzędzia badawczego. Przegląd Gastroenterologiczny. 2009; 4 (2): 88-92.

17. Larsson K., Lööf L., Rönnblom A., Nordin K.: Quality of life for patients with exacerbation in inflammatory bowel disease and how they cope with disease activity. J. Psychosom. Res. 2008; 64: 139-148.

18. Henrich G., Herschbach P.: Questions on life satisfaction (FLZM)- a short questionnaire for assessing subjective quality of life. Eur. J. Psychol. Assess. 2000; 16: 150-159.

19. Hebzda A., Szczeblowska D., Serwin D.S. i wsp.: Choroba Leśniowskiego-Crohna - diagnostyka i leczenie. Pediatr. Med. Rodz. 2011; 7 (2): 98-103.

20. Wejman J., Bartnik W. (red): Atlas kliniczno-patologiczny nieswoistych chorób zapalnych jelit. Termedia Wydawnictwa Medyczne, Poznań 2011, wydanie I.

21. Bączyk G., Karoń J., Krokowicz P. et al.: Assessing quality of life among patients with inflammatory bowel disease treatment on surgical ward. Proktologia. 2008; 9: 172-182.

22. Petryszyn P., Ziółkowska J., Paradowski L.: Nieswoiste zapalenia jelit w ubezpieczeniu rentowym -przegląd piśmiennictwa. Przegl. Gastroenterol. 2008; 3 (5): 237-242.

23. Bernklev T., Jahnsen J., Lygren I. et al.: Health- related Quality of Life in Patients with Inflammatory Bowel Disease Measured with the Short Form-36: Psychometric Assessments and a Comparison with General Population Norms. Inflamm. Bowel Dis. 2005; 11 (10): 909-918.

Word count: $3500 \quad$ Page count: $7 \quad$ Tables: $3 \quad$ Figures: $4 \quad$ References: 23

DOI: $\quad 10.5604 / 01.3001 .0010 .3904$

Table of content: http://ppch.pl/resources/html/articlesList?issueld=10336

Copyright: Copyright @ 2017 Fundacja Polski Przegląd Chirurgiczny. Published by Index Copernicus Sp. z o. o. All rights reserved.

Competing interests: The authors declare that they have no competing interests.

The content of the journal „Polish Journal of Surgery" is circulated on the basis of the Open Access which means free and limitless access to scientific data.

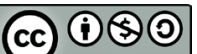
BY NC SA

Corresponding author:

Cite this article as:

This material is available under the Creative Commons - Attribution 4.0 GB. The full terms of this license are available on: http://creativecommons.org/licenses/by-nc-sa/4.0/legalcode

Joanna Chrobak-Bień; Klinika Chorób Przewodu Pokarmowego, Uniwersytecki Szpital Kliniczny nr 1 w Łodzi, Studia doktoranckie, Wydział Lekarski, Uniwersytet Medyczny w Łodzi, e-mail: aska1105@interia.pl

Chrobak-Bień J., Gawor A., Paplaczyk M., Gąsiorowska A.; Analysis of factors affecting the quality of life of those suffering from Crohn's disease; Pol Przegl Chir 2017: 89 (4): 16-22 
